\title{
Graphic and Functional Algorithms of Sequence of Tenses in English Grammar for the Effective Education and Automated Systems of Text Synthesis and Editing
}

\author{
Ludmila Kozlova \\ National Research University Higher School of Economics \\ Correspondence concerning this article should be addressed to Ludmila Kozlova , National Research \\ University Higher School of Economics, Kirpichnaya, 33, Moscow, Russian Federation, 105187. E-mail: \\ lkozlova@hse.ru
}

Nadejda Trubochkina

National Research University Higher School of Economics

\begin{abstract}
Correspondence concerning this article should be addressed to Nadejda Trubochkina, National Research University Higher School of Economics, Tallinskaya, 34, Moscow, Russian Federation, 123458. E-mail: ntrubochkina@hse.ru
\end{abstract}

\begin{abstract}
The article describes the optimal graphic language of presenting and studying English grammar using information technology. Among the studies on the use of graphics in teaching a foreign language, there are mostly descriptions of static objects. The authors propose to use a universal graphic language for describing processes. The authors suggest theoretical foundations of visualization of the English grammar rules using time-sequential conversion scale in the sequence of tenses transformation. The research question is the method of archiving knowledge of English grammar to simplify and speed up the memorization and to increase the volume of information memorized. To achieve this goal, the authors used a graphic algorithmization of the English grammar and visualization of grammar rules, as well as the comparative monitoring of the knowledge gained. As part of research, a series of experiments on the visualization of the rules of sequence of tenses were conducted in student groups. The research showed that a simple language of symbols facilitates and accelerates the memorization of English grammar. Systematic tabulation of grammar rules, where each verb tense gets its finished graphic image, becomes easy to understand and quick to memorize. The application of the presented approach is the following: effective linguistic education, local and global automatic synthesis system and text editing.
\end{abstract}

Keywords: visualization, optimal graphic language, interdisciplinary study, information technology, English grammar, essentially temporal processes

Visualization is a tool to represent regularities or patterns. It uses human visual system as an additional subsystem to a system of data mining, for example, perceived by a person in the study of any language. People begin to think of using another tool that is eyes. This approach (i.e., visualization) seems to be effective in various spheres of human activity: from programming in intelligent systems to learning a foreign language. Working on the English grammar, learners of all age have difficulties when studying some of its sections. For example, the conversion of a direct speech into an indirect one and the sequence of tenses, related to this, present great difficulties. The process of memorizing and gaining skills of specific 
rules and practical application takes considerable time. In this article the previous research (Kozlova, Trubockina, 2014, pp. 223-232) is continued to develop schemes (images) that are easily absorbed by the human memory, because of its conciseness and imagery.

\section{Materials and Methods}

The technique of presenting grammar material is very traditional in Russian methodical and scientific literature as well as in English (Capel, 2012, pp. 112119; Cotton, 2010, pp. 154-155; Hastings, 2010, pp. 202-204; Kay, 2007, pp. 68-87, and others). In various textbooks issued by British publishers a consistent presentation of complex grammar rules is used. Besides, it is burdened by many nuances that are additional difficulties for students. This applies to the learning-aids, for example, special tables and graphs in this research for practical learning of English.

Higher School of Economics researchers develop and study various techniques in the field of English linguistics and effectiveness of teaching English (Velikaya, 2014, pp. 25-30). Their research also contributed to the study in question. After analyzing different methods of teaching the English grammar in the studies mentioned above, a very interesting and, in our opinion, the best way to learn English through the introduction of information technologies in linguistics is offered, i.e. visualization of English grammar rules and presentation of the most difficult sections with graphic algorithms. It should be noted that the graphic algorithms have been used for recording texts since ancient times.

\section{Graphic Languages of Communication}

The first mention of a graphic language dates back to about 3200 BC (Sumerians in Mesopotamia). The Sumerians used the drawings - the words, the socalled pictograms (Dyakonov, 1990, pp. 3-685). That was also when the symbolic language of words-images appeared in China (Kondrashevskiy, 1998, p. 9). In the language there was a simple image of conventional notions of «horse, fish, sun, water, fire, rain, etc. » as the original semantic basis for each character in most cases. In the course of time, the image was transformed into hieroglyphic symbols. Word-pictures also turned into a special kind of writing - cuneiforms (Istoriya pisma, 2002, p. 23). The icons were used by Egyptians (3000 BC.). In the Egyptian hieroglyphic writing system words, sounds and letters are denoted by symbols (Petrovskiy, 1958, pp. 52-53). The Aztecs' writing icons depicted numbers: points were used for the numbers from 1 to 19 , a flag - for the number of 20 , a pen - for 400, a bag full of beans - for the number of 8000 (Talah, 2013, pp. 39-42). The semantic concepts of «who», «what» and «how much» were typical of graphic languages of communication in which there were very few signs of connections, actions and sequences.

\section{Visual Programming Languages}

In addition to the visual (graphic) languages of communication, there are visual programming languages, in which the relationships between objects, actions, and their sequences are involved in the description processes, together with the objects on an equal footing (Johnston, 2004, p. 7).Visual programming languages appeared in the 20th century as an adjunct to the visualization of conventional programming languages. In 1984, Jaron Lanier published an article about a visual programming language (Jaron Lanier, http://www.well.com/user/jaron), which was followed by the birth of several visual programming languages, such as:

- «Dragon (Friendly Russian algorithmic language that provides visibility)» used in the rocket and space technology, which can be attributed to the language of diagrams or flowcharts (Zenkin, 1991, pp. 96-113);

- The basic elements of the language are states (shown by rectangles), which perform certain actions and transitions from state to state (lines). For each transition, a logical condition for the transition to the next step is assigned;

- «LD (Ladder Diagram)» - a graphic language for programming ladder diagrams (Parr, 2007, p. 34);

- «FBD (Function Block Diagram)» - graphic language to describe the functional block diagrams (Petrov, 2004, pp. 19-21, 48-64);

- «CFC (Continuous Flow Chart)» - graphic language created for the design of control systems with continuous technological processes;

- «LabVIEW» - a graphic language for programming working with non-PC devices (http://www.labview. $\mathrm{ru} /, 2015)$;

- «VisSim»-a graphic language for modeling dynamic systems and designing systems based on models with built-in microprocessors (Darnell, 1996, p. 14);

- «Scratch»- a visual object-oriented educational environment for students (Super Scratch Programming Adventure! Learn to Program, 2012, pp. 5-160);

\section{Visualization of Sound (Music) Information}

There is very little information of the ancient notations. It is assumed that in ancient Babylon they used pictographic record; in Ancient Egypt syllable record was used (Brokgauz, Efron, 1890-1907). The first records of musical notation are ancient Greek 
ones. They are the samples of the Letter notation. Liturgical monophony was recorded in neumes (IX c.), which did not specify the exact height and duration of sounds, but only a rough plan of melody directions. By the beginning of the XI century neumes were written on (horizontal) lines and between them. "Linear" modification allowed to register the pitch, but still did not determine rhythmic durations of the sound. Based on graphs of square notation the so-called modal (from Lat. Modus, i.e. measure) notation, the first in the history of rhythm, was developed at the end of the XII century. Modal notation was replaced by Mensural one that accurately determined not only the pitch intervals but also rhythmic duration. Prior to 1450 «black notation» (i.e. notes head painted in black) was used. Later "white notation» was gradually introduced, in which the heads of notes of long duration were not painted. In the second half of the XX century composers began to use a number of specific forms of records to reflect special effects of the sound - the sound masses, vibrato, and so forth. The modern five-line beat notation is the most common form of writing music today. One of the main elements of music notation is a line, in fact, the time-scale on which all other graphical elements are placed. So familiar to us musical notation is a music record in a kind of graphic language, where not only symbols (notes), but also the time-frequency rhythmic character of playing is taken into account (Dubinets, 1999, p. 23; Bershadskaya, 1988, p. 32). To describe a complex section of English grammar - the sequence of tenses, the advantage of the approach also based on the timeline was taken (see Tables 1-3).

\section{Research Context}

This work is originated at the lessons of English grammar. It was performed at the junction of Information Technologies, English linguistics and methodology of education.

In 2013-2015 the Department of Foreign Languages at the NRU Higher School of Economics conducted an experiment to introduce methods of teaching English using the visualization of the English grammar rules. Within 2 years, a comparative monitoring of teaching English was carried out. All the students took the test before they were taught grammar with the help of the new visual tool and a similar test after that. The monitoring results are presented in Tables $1-3$. The monitoring of research was carried out in 2013-2014 (302 students) and in 2014-2015 (310 students).

\section{Gradual and Parallel Perception of Information}

People perceive information differently. At first, reading the rules of the English grammar, one reads a page of text sequentially word by word to better understand the meaning. It can take several minutes (sequential data input). Every time it is necessary to put this knowledge into practice, people read this information in their minds again. The more practice, the faster playback, but still the process remains very slow. Therefore, the traditional method of learning English can be optimized with respect to time while maintaining the quality. Easily formalized text rules should be easily replaced by pictures. If the pictures are binary (computer counting system, the text in a symbolic language), not only the human brain will perceive them faster. But the maximum possible formalization of the language on the computer will be possible. One of the main developers of this language Neil Fraser believes that the main purpose of it is "an attempt to climb to a higher level of abstraction, to deny programming caste and secrecy, to make it more natural and accessible to the widest possible range of people" (https://neil.fraser.name/ news/2012/01/24/). The amount of information to store and playback is significantly less than that of textual information, where a block can be a letter, a number, a symbol or a text. So the time to understand and remember texts in a formal visual language is reduced significantly. In mathematical logic and computer science a formal language is a set of finite words in a finite alphabet. And if it is possible to reduce the number of symbols in the alphabet without loss of understanding of the transmitted information you can get acceleration of information perception in a computer as well as ease of understanding and remembering of information by a person.

\section{Research Methods}

The authors suggested theoretical foundations of visualization of the English grammar rules using time-sequential conversion scale in the sequence of tenses transformation. The authors used a graphic algorithmization of the English grammar and visualization of grammar rules as a method of archiving knowledge to intensify teaching English. At the end of the research the comparative monitoring of the knowledge gained was conducted.

\section{Sequence of Tenses Visualization}

Graphics based on the algorithm of the sequence of tenses have a clock-time model, shown in the following graph:

Horizontal lines in the timelines A and B correspond to the verb tenses (past, present and future).

Solid vertical lines delimit beat cycles in which there are initial $\left(f_{i}, i=1, \ldots n 1\right)$ and transformed $\left(p_{i}\right.$, $i=1 \ldots n 2)$ linguistic forms. Inside tact cycles there are subbeats of initial $\left(t_{i}, i=1 \ldots n 3\right)$ and transformed 


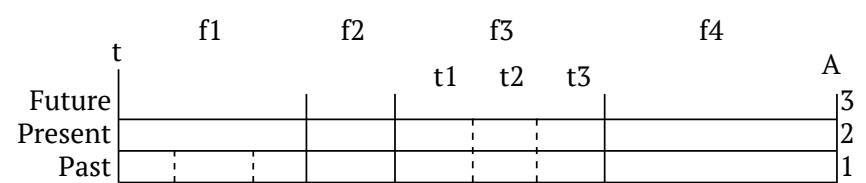

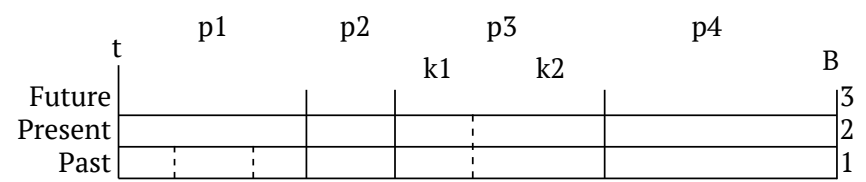

Figure 1. Basis of graphics algorithms of tenses of English grammar.

$\left(\mathrm{k}_{\mathrm{i}}, \mathrm{i}=1 \ldots \mathrm{n} 4\right)$ cycles. Vertical dashed lines delimit subbeats. The initial sentence is placed on the timeline $\mathrm{A}$, and the transformed one - on the timeline $\mathrm{B}$.

The transformation of linguistic forms can be considered through the following example.

The original sentence:

A. He asked me: "What will you do tomorrow?" (1)

According to the rules of sequence of tenses, the transformed sentence will be as follows:

B. He asked me what I would do the next day (2)

When converting a direct speech into the reported one (retelling of direct speech) if the main clause is in the past tense, the following changes occur:

- the verb tense in the subordinate clause changes (in accordance with the rules of the sequence of tenses: Future Simple into Future-in-the-Past);

- the word order is direct (as in declarative sentence);

- pronouns change accordingly within the meaning of the utterance.

These sentences are placed on the timeline A and B (Fig. 2) and the conversion is analyzed.

The first beat of the transformed sentences $\mathrm{p} 1$, containing three subbeats differs from the first beat of the original sentence in lack of text constant ":" in the fourth subbeat ( $t 4)$ of the first beat in the original sentence. The conversion of the first beat may be functionally represented as $\mathrm{f} 1(\mathrm{~T} 1, \mathrm{t} 2, \mathrm{t} 3, \mathrm{t} 4) \rightarrow \mathrm{p} 1 \mathrm{v}$ (T1, $\mathrm{v} t 2 \mathrm{v}, \mathrm{t} 3)$. The subbeat, beginning with a capital letter, corresponds to the word with a capital letter. The third and fourth beats vary according to the rule: $\mathrm{f} 3 \mathrm{f} 4 \rightarrow \mathrm{p} 3$ p4.

\section{The Models of Information Transformation. The Example of Converting Direct Speech into Reported Speech}

In addition to standard text and sound patterns for the language study which explain the transformation of direct speech into reported one there are three more models of transformation related to applications of information technologies in linguistics. They are the following:

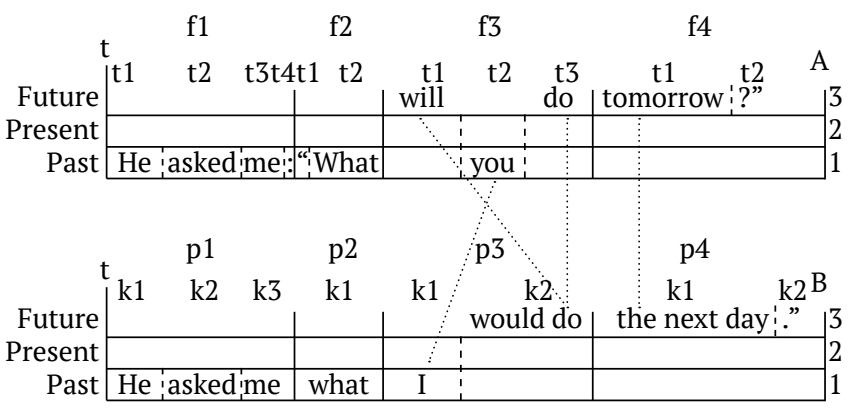

Figure 2. Example of graphic algorithms of sequence of tenses in English grammar.

1. Graphic model (visual - the drawing of actions) (Fig. 2);

2. The mathematical model (Fig. 3);

3. The algorithmic model (different types of recording) (Fig. 4).

\section{Graphic Model}

Graphic model, in fact, is a graphical representation of the mathematical and algorithmic models. However, unlike the latter, it is performed (memorized) not sequentially, analyzing each element of the model (cells in two tables of the mathematical model and algorithm blocks in the diagrams), but in parallel, i.e. immediately.

To understand the difference between gradual and parallel perception it is necessary to compare it with the gradual and parallel reception of information in computers.

For sequential administration, the information of one cell in the matrix is memorized at a time. The larger is the size of the information matrix, the more time is required for its memorizing and processing.

In parallel reception, the information from all the cells of the matrix is memorized at a time, regardless of its size.

For the second beat functional transformation is described as $\mathrm{f} 2$ («“»T2) $\rightarrow \mathrm{p} 2$ (t2). The conversion algorithm of the third beat is as follows: $\mathrm{f} 3$ ( $\mathrm{t} 1, \mathrm{t} 2$, $\mathrm{t} 3) \rightarrow \mathrm{p} 3(\mathrm{k} 1, \mathrm{k} 2)$, where $\mathrm{k} 1 \mathrm{~m}=\mathrm{t} 2 \mathrm{~m}-1$, which means that the first subbeat of the transformed sentence has got a transformed linguistic form from the second subbeat of the third beat in the original sentence. The pronoun "you" becomes "I". Forming a second subbeat the third beat occurs according to the following algorithm: $\mathrm{k} 2=\mathrm{t} 1 \mathrm{vF}-1 \rightarrow \mathrm{t} 3$. This means that the new linguistic form in the second subbeat will be built from the converted first subbeat of original form and the linguistic form of the third subbeat. The algorithm t1vF-1 means that the auxiliary verb (v) in the future tense (F) will have a lower temporary rating, e.g., "will" is converted to "would" (Future-inthe-Past). The fourth beat is also a subject to change. 


\begin{tabular}{|c|c|c|c|c|}
\hline \multirow[t]{2}{*}{ A } & & \multicolumn{3}{|c|}{ Timeline } \\
\hline & & Past & Present & Future \\
\hline \multirow[t]{4}{*}{ f1 } & $\mathrm{t} 1$ & $\mathrm{He}$ & & \\
\hline & $\mathrm{t} 2$ & asked & & \\
\hline & $\mathrm{t} 3$ & me & & \\
\hline & $\mathrm{t} 4$ & : & & \\
\hline \multirow[t]{2}{*}{$\mathrm{f} 2$} & $\mathrm{t} 1$ & “ & & \\
\hline & $\mathrm{t} 2$ & What & & \\
\hline \multirow[t]{3}{*}{ f3 } & $\mathrm{t} 1$ & & & will \\
\hline & $\mathrm{t} 2$ & you & & \\
\hline & $\mathrm{t} 3$ & & & do \\
\hline \multirow[t]{2}{*}{$\mathrm{f} 4$} & $\mathrm{t} 1$ & & & tomorrow \\
\hline & $\mathrm{t} 2$ & & & ?” \\
\hline
\end{tabular}

\begin{tabular}{llll}
\hline \multicolumn{3}{c}{ B } & \multicolumn{3}{c}{ Timeline } \\
\hline $\mathrm{f} 1$ & $\mathrm{k} 1$ & $\mathrm{He}$ & \\
\hline & $\mathrm{k} 2$ & asked & \\
\hline & $\mathrm{k} 3$ & $\mathrm{me}$ & \\
\hline & $\mathrm{k} 4$ & & \\
\hline $\mathrm{f} 2$ & $\mathrm{k} 1$ & & would \\
\hline & $\mathrm{k} 2$ & what & do \\
\hline $\mathrm{f} 3$ & $\mathrm{k} 1$ & $\mathrm{I}$ & the next day \\
\hline & $\mathrm{k} 2$ & & . \\
\hline
\end{tabular}

Figure 3. Mathematical model of transformation of direct speech into indirect.

The adverbial modifier of time "tomorrow" in the first subbeat is replaced by an analogue (a) "the next day", i.e., $\mathrm{f} 4(\mathrm{t} 1) \rightarrow \mathrm{p} 4$ (t1) a. Punctuation marks also change at the end of sentences (“?” $\rightarrow$ “.”). Thus, functional graphic recording of the algorithm (a compressed algorithm for computing transformation) for this example is as follows:

$$
\begin{aligned}
& \mathrm{f} 1(\mathrm{~T} 1, \mathrm{t} 2, \mathrm{t} 3, \mathrm{t} 4) \mathrm{f} 2(\mathrm{t} 1, \mathrm{~T} 2) \mathrm{f} 3(\mathrm{t} 1, \mathrm{t} 2, \mathrm{t} 3) \mathrm{f} 4(\mathrm{t} 1) \text { “?” } \rightarrow \\
& \mathrm{p} 1(\mathrm{~T} 1, \mathrm{t} 2, \mathrm{t} 3) \mathrm{p} 2(\mathrm{t} 2) \mathrm{p} 3\left(\mathrm{t} 2_{\mathrm{m}^{-1}}, \mathrm{t} 1_{\mathrm{vF}^{-1}} \& \mathrm{t} 3\right) \mathrm{p} 4(\mathrm{t} 1) \mathrm{a} \text { “.” }
\end{aligned}
$$

It should be noted that if the functional listing is a compressed general algorithm for computer editing systems, a graphical algorithm is an effective teaching aid in the study of the English language, because all rules are remembered "at a glance".

\section{Mathematical Model}

The mathematical model of conversion of English direct speech into reported one can be considered as transformation of matrix A into matrix B (Fig. 3).

The tables show that it is not necessary to form a completely new matrix of reported speech. It is created from the matrix of direct speech changing the information in some cells according to the model. So only 5 of 33 cells of the matrix are changed. This is a very good efficacy in the formation of a new information image.

Algorithmic Model (Algorithm Diagram)

The algorithmic model (sequential) is shown in Figure 4. It is simple enough to write a script (conversion program) according to the model. Since the algorithmic model is written according to the mathematical one (using the language of algorithm diagrams), the formation of a new information image (reported speech based on direct speech) has the same efficiency as that of the mathematical model, i.e. (33-5) / $33 * 100 \%=$ $71.9 \%$.

The efficiency (resource saving) is considered the percentage of the amount of unused iterations to the total number of iterations in the formation of an information image.

Since the subject of this article is a new method of teaching English using graphic models, mathematical and algorithmic models will not be further presented.

\section{Graphic Algorithms of Sequence of English Verb Tenses and Their Functional Listing}

The reported speech in the English grammar is closely related to the sequence of tenses.

If the main clause has a verb in the Present tense, no change occurs.

He says he will do it tomorrow (Future Simple).

He says that we read a lot (Present Simple).

He says he is trying to learn this (Present Continuous).

He says he has just met them (Present Perfect).

He says he met her yesterday (Past Simple).

He says he has been working here since childhood (Present Perfect Continuous).

If the verb in the main clause is in the Past Simple or Past Continuous, then there are the following changes: 
He said they would come later.

He said he liked cats.

He said he was reading the book.

He said he had met Peter two days before.

He said he had been working there since childhood.

In other words, this is as follows:

Future-in-the-Past

Past Simple-Past Simple, Past Continuous

Past Perfect; Past Perfect Continuous

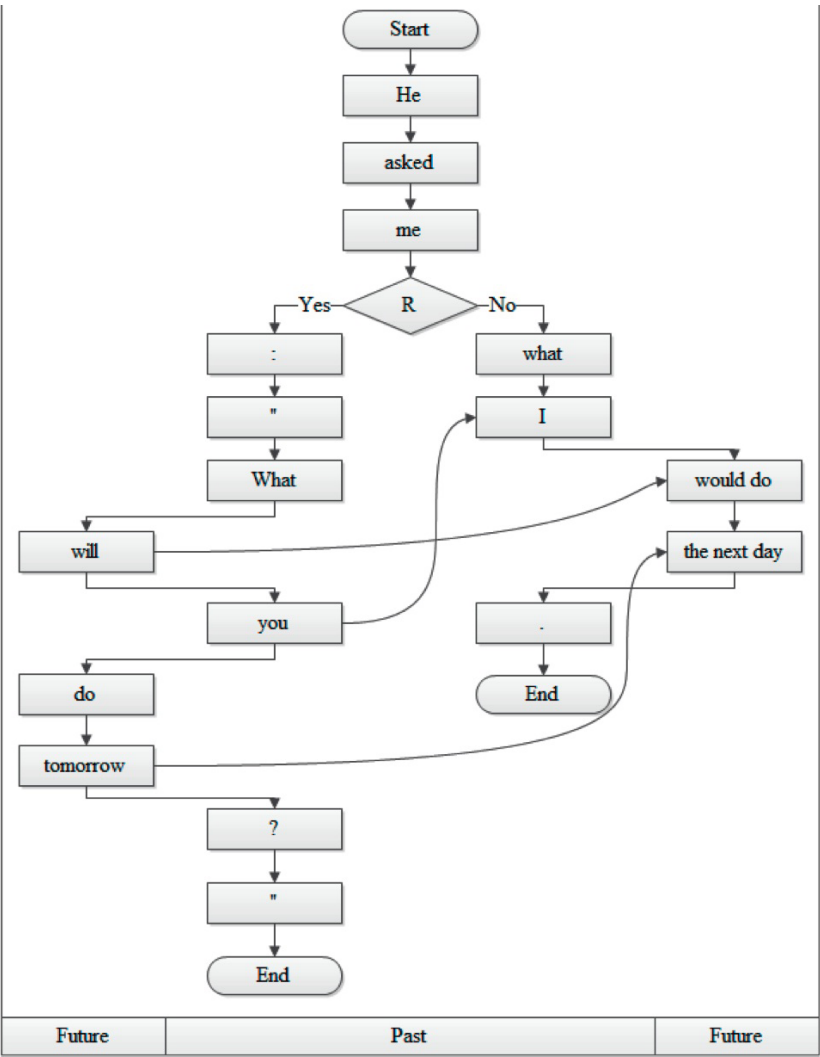

Figure 4. Algorithmic model (algorithm diagram) of direct speech conversion into reported speech.

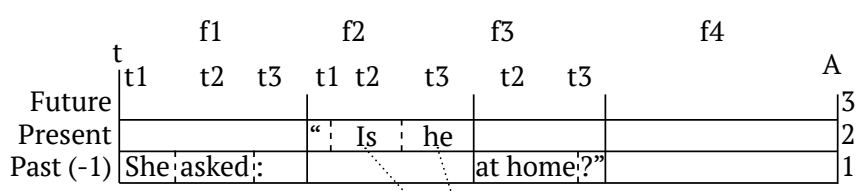

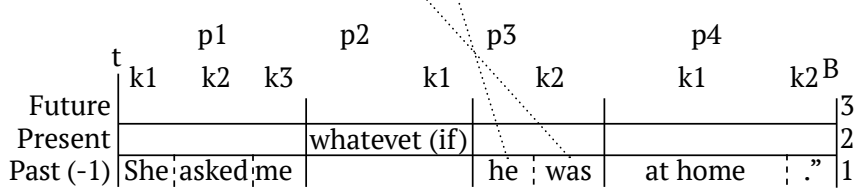

Figure 5. The graphic algorithm of sequence of English verb tenses in general questions.
Thus, the verb tense in the subordinate clause is amended as follows:

Future Simple - becomes Future-in-the-Past

Present Simple - Past Simple

Present Continuous - Past Continuous

Present Perfect Continuous - Past Perfect Continuous

Past Simple - Past Perfect

Conditionals - do not change.

In interrogative sentences some changes occur:

1 -verb tense;

2-pronoun;

3-adverbial modifier of time;

4-adverbial modifier of place;

5 -word order.

In general questions a subordinate clause is introduced by auxiliary words "if" or "whether" (Fig. 5).

A. She asked: "Is he at home?"

B. She asked me whether (if) he was at home.

Based on the above rules functional listing of graphic algorithm (compressed algorithm for computer transformation of general questions) would be as follows:

$$
\begin{gathered}
\mathrm{f} 1(\mathrm{~T} 1, \mathrm{t} 2 \text {, “:”) f2 f3(t1,t2,t3) } \mathrm{f} 4 \rightarrow \\
\mathrm{p} 1(\mathrm{~T} 1, \mathrm{t} 2 \text {, “me”) p2(“whether|if”) p3(k1=f2(t3) k2= } \\
\text { f2(t2vb-1,) p4(k1=f3(t1) “.” }
\end{gathered}
$$

where:

- "me", "whether or if", "." - Inserted linguistic constants; - t1vb-1 - verb (vb) - the Present tense converted to the Past tense.

In special questions: see 5 and figure 2 .

In imperative sentences a subordinate clause is introduced with the help of the Infinitive (positive or negative).

1. Positive infinitive (Fig. 6).

A. She told me: "Go to the kitchen."

B. She asked me to go to the kitchen.

The algorithm for computer transformation of an imperative sentence would be as follows:

$$
\begin{aligned}
& \text { f1 (T1, t2, t3, “:”) f2 («”», T2, t3) f3 (“.”) } \rightarrow \\
& \text { p1 (T1, t2M, t3) p2 (“to”f2(t2),t3)) p3=f3 }
\end{aligned}
$$

where “:”, “.” “, ““””, "to” are text constants;

t2M is upgraded linguistic form (transformation of "told" into "asked," ...).

2. Negative infinitive (Fig. 7).

A. Bob said: «Don't be late! »

B. Bob asked me not to be late.

The algorithm for computer transformation of an imperative sentence would be as follows:

$\mathrm{f} 1(\mathrm{~T} 1, \mathrm{t} 2, \ll: ») \mathrm{f} 2($ («"»,T2,t3) f3 (t1) f4=«.”» $\rightarrow$

$\mathrm{p} 1(\mathrm{t} 1, \mathrm{t} 2 \mathrm{M}$, «me») $\mathrm{p} 2($ (not», «to») p3=f3 p4=«.»

- «:», «"», «"», «."»» «to», «me», «not» are text constants;

- t2M is upgraded linguistic form (transformation of

"said" into "asked," ...). 


\section{Practical Application}

The areas of practical application of the proposed approach are:

for functional algorithms:

- intelligent Internet (automated editing of English texts);

- automatic local systems of text editing;

for graphic algorithms:

- effective linguistic education.

\section{Results and Discussion}

\section{Comparison of Basic and Graphic Language Methods of Teaching English}

Table 1 shows the overall results in monitoring, where the quality of teaching $(\mathrm{K})$ is determined by the number of excellent and good ratings of the test participants (marks $10-6$ ) in relation to the total number of tested students before and after the introduction of the new technique:

$$
K=\frac{\sum_{i=6}^{10} N i}{N}
$$

where $\mathrm{Ni}$ - is the number of marks equal to I score, $\mathrm{N}$ total number of participants. Table 1 shows the overall results of the comparative monitoring in 2013-2015: 2013-2014 - basic course (BC); 2014 - 2015 - basic course using graphic language to explain the rules of English grammar (GL). Overall monitoring results are also given in Figure 8.

Table 1 presents the results of monitoring of two streams of students. In the first stream (302 students) a basic grammar course was taught, but in the second stream (310 students) a basic course with the use of graphic language was taught.

Analyzing the graphs, students and lectures can conclude about improving the quality of teaching English at the expense of increasing the excellent and good grades (the range of 10 to 7 points).

There was a second study of the analysis of changes in marks in the test with the introduction of graphic techniques in different groups of students included:

1. Students managers.

2. Students logistic managers.

3. Lecturers - students in the Center of Professional Advancement (CPC).

4. Free listeners (small groups).

Table 2 shows the results of the monitoring of the same students, but divided into professional (managers, logistitic managers, lectures students, free listeners) and time-groups (2013-2014, 2014-2015).

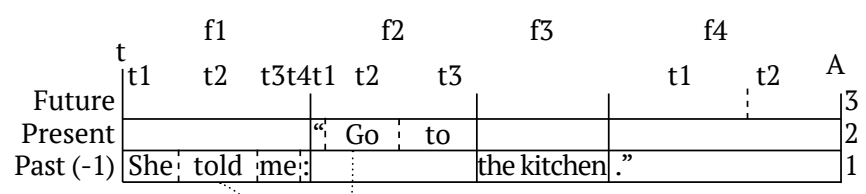

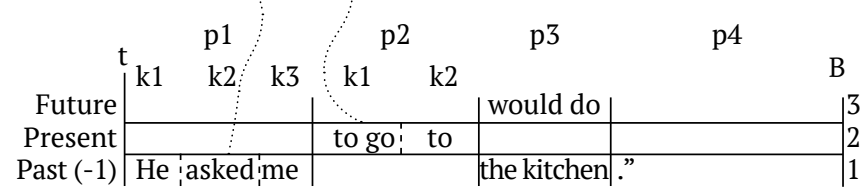

Figure 6. Graphic algorithm of sequence of verb tenses in the imperative sentence (Positive infinitive).

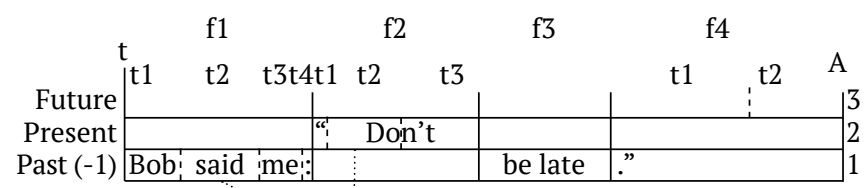

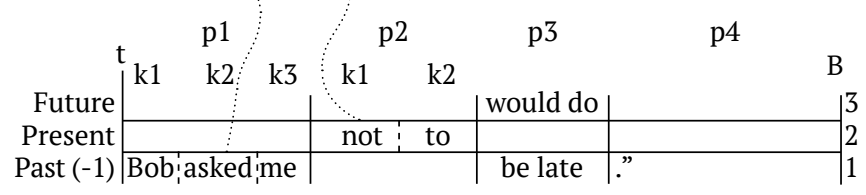

Figure 7. Graphic algorithm of sequence of verb tenses in the imperative sentence (Negative infinitive).

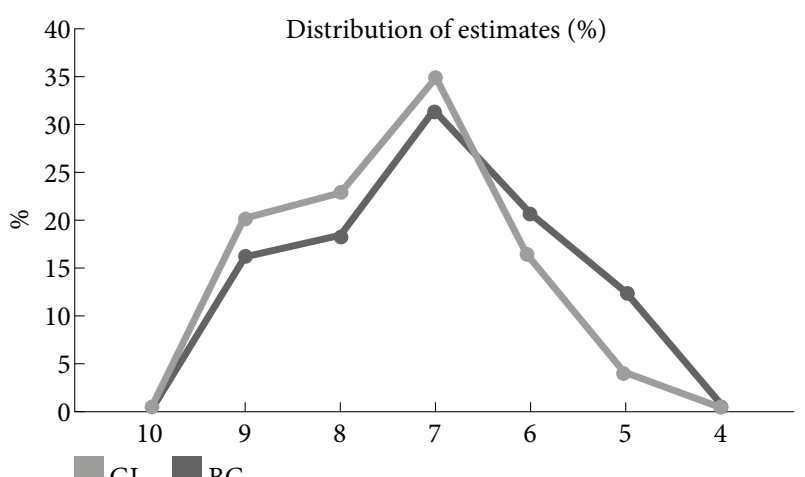

Figure 8. Total distribution of scores in percentage: BC - basic course GL - using graphic language. The horizontal axis $10-10$ points, 9 - 9 points, etc.

Table 2, as well as Table 1, presents the improved results of the English grammar studying. The managers group (Figure 9) increased the relative number of scores 7 and 8 . The logistics managers group (Figure 11) showed the same result. In groups of lectures (Figure 10), the trend was the same trend, but the scores increeased to 8 and 9.

Figures 9 to 12 pool information on the results of graphics algorithms and visualization rules introduction in sequence of English tenses teaching.

From the graphs in Figures 9-12 it can be a trend of general studies - an increase of excellent and good ratings (range 10-7 points), which manifests itself in different degrees in different groups of students. 
Table 1

Overall monitoring results in 2013-2015

\begin{tabular}{|c|c|c|c|c|c|}
\hline \multirow[b]{2}{*}{ Total students tested } & \multirow{2}{*}{$\frac{\text { Variables }}{\mathrm{N}}$} & \multicolumn{2}{|c|}{ Basic course (BC) } & \multicolumn{2}{|c|}{ Graphic Language (GL) } \\
\hline & & \multicolumn{2}{|c|}{302} & \multicolumn{2}{|c|}{310} \\
\hline \multicolumn{6}{|c|}{ Evaluation of students' tests } \\
\hline & & Amount & $\%$ & Amount & $\%$ \\
\hline Excellent (10) & N10 & 0 & 0 & 1 & 0,3226 \\
\hline Excellent (9) & N9 & 47 & 15,563 & 64 & 20,645 \\
\hline Excellent (8) & N8 & 51 & 16,887 & 69 & 22,258 \\
\hline Good (7) & N7 & 101 & 33,444 & 110 & 35,484 \\
\hline Good (6) & N6 & 63 & 20,861 & 53 & 17,097 \\
\hline Satisfactory (5) & N5 & 37 & 12,252 & 11 & 3,5484 \\
\hline
\end{tabular}

Table 2

Comparative analysis of the quality of English in methods of teaching English with the use of graphic language in different groups of students

\begin{tabular}{|c|c|c|c|c|c|c|c|c|c|}
\hline & & \multicolumn{8}{|c|}{$\begin{array}{l}\mathrm{N}-\text { number of students / number of marks: N4 - number of good and } \\
\text { excellent marks (4-9)...N10 - number of excellent marks (10) }\end{array}$} \\
\hline & & $\mathrm{N}$ & N4 & N5 & N6 & N7 & N8 & N9 & N10 \\
\hline \multirow[t]{2}{*}{ BC } & \multirow{2}{*}{$\begin{array}{l}\text { Students managers } \\
2013-2014\end{array}$} & 120 & 11 & 17 & 28 & 34 & 14 & 16 & 0 \\
\hline & & $100 \%$ & 9,17 & 14,17 & 23,33 & 28,33 & 11,67 & 13,33 & 0,00 \\
\hline \multirow[t]{2}{*}{ GL } & \multirow{2}{*}{$\begin{array}{l}\text { Students managers } \\
2014-2015\end{array}$} & 128 & 8 & 15 & 22 & 42 & 18 & 23 & 0 \\
\hline & & $100 \%$ & 6,25 & 11,72 & 17,19 & 32,81 & 14,06 & 17,97 & 0,00 \\
\hline \multirow[t]{2}{*}{ BC } & \multirow{2}{*}{$\begin{array}{l}\text { Students logistic } \\
\text { managers 2013-2014 }\end{array}$} & 105 & 8 & 12 & 24 & 42 & 9 & 10 & 0 \\
\hline & & $100 \%$ & 7,62 & 11,43 & 22,86 & 40,00 & 8,57 & 9,52 & 0,00 \\
\hline \multirow[t]{2}{*}{ GL } & \multirow{2}{*}{$\begin{array}{l}\text { Students logistic } \\
\text { managers 2014-2015 }\end{array}$} & 109 & 6 & 11 & 15 & 48 & 15 & 13 & 1 \\
\hline & & $100 \%$ & 5,50 & 10,09 & 13,76 & 44,04 & 13,76 & 11,93 & 0,92 \\
\hline \multirow[t]{2}{*}{$B C$} & \multirow{2}{*}{$\begin{array}{l}\text { Lecturers - students } \\
\text { in the Center } \\
\text { of Professional } \\
\text { Advancement } \\
2013-2014\end{array}$} & 49 & 6 & 10 & 8 & 10 & 8 & 7 & 0 \\
\hline & & $100 \%$ & 12,24 & 20,41 & 16,33 & 20,41 & 16,33 & 14,29 & 0,00 \\
\hline \multirow[t]{2}{*}{ GL } & \multirow{2}{*}{$\begin{array}{l}\text { Lecturers - students } \\
\text { in the Center of Pro- } \\
\text { fessional Advance- } \\
\text { ment 2014-2015 }\end{array}$} & 53 & 3 & 5 & 7 & 18 & 11 & 9 & 0 \\
\hline & & $100 \%$ & 5,66 & 9,43 & 13,21 & 33,96 & 20,75 & 16,98 & 0,00 \\
\hline \multirow[t]{2}{*}{$\mathrm{BC}$} & \multirow{2}{*}{$\begin{array}{l}\text { Free listeners } \\
2013-2014\end{array}$} & 28 & 0 & 0 & 1 & 2 & 13 & 12 & 0 \\
\hline & & $100 \%$ & 0,00 & 0,00 & 3,57 & 7,14 & 46,43 & 42,86 & 0,00 \\
\hline \multirow[t]{2}{*}{ GL } & \multirow{2}{*}{$\begin{array}{l}\text { Free listeners } \\
2014-2015\end{array}$} & 20 & 0 & 0 & 0 & 1 & 9 & 9 & 1 \\
\hline & & $100 \%$ & 0 & 0 & 0 & 5 & 45 & 45 & 5 \\
\hline
\end{tabular}




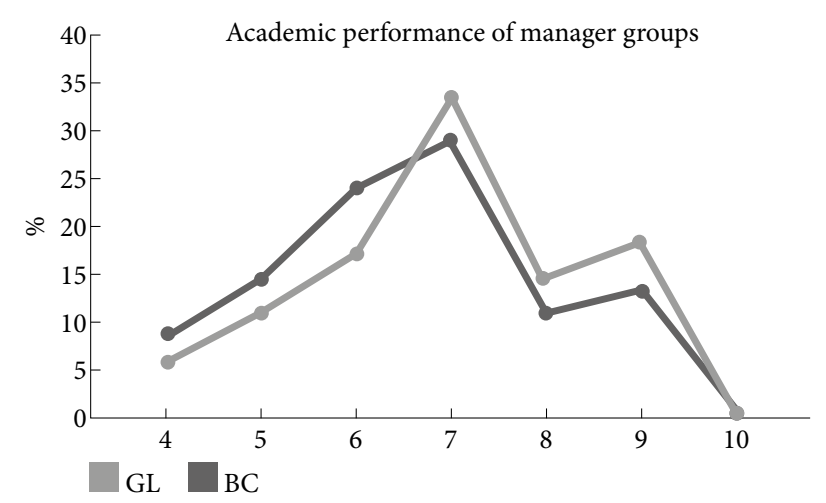

Figure 9. The distribution of scores (from 4 to 10 points) in groups of students-managers using basic techniques $(\mathrm{BC})$ and a technique using the graphic language (GL).

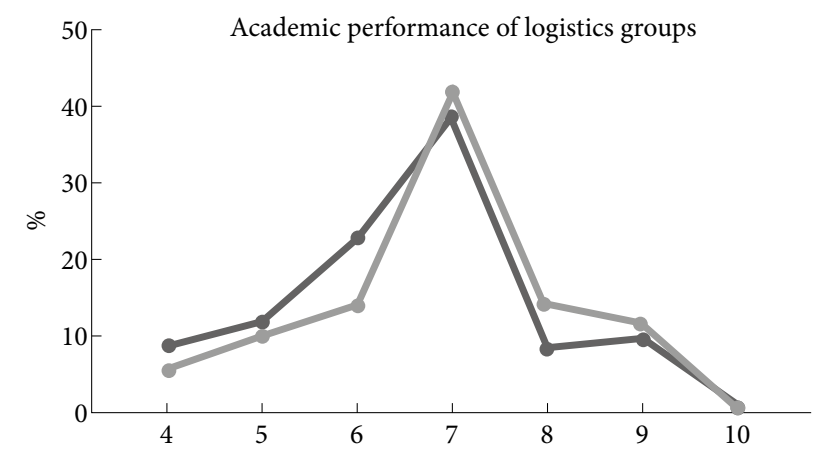

GL $\quad \mathrm{BC}$

Figure 11. Distribution of ratings (from 4 to 10 points) in the group of lecturers - students in the Center of Professional Advancement using basic techniques (BC) and methods of using the graphic language (GL).

An integrated assessment of quality indicators improvement (increased number of evaluations in the range of 7-10 points) for different types of students is presented in Table 3 .

Figure 13 shows an integrated assessment the quality improvement in teaching English with the introduction of new techniques for different types of audiences.

Based on these graphs, the following conclusions can be drawn:

With the introduction of the graphic language, visualizing the rules of English grammar, the number of excellent and good ratings in the range of 7-10 points increased by an average of 3\% in all types of groups:

1. groups of HSE students managers - by $2,88 \%$;

2. groups of HSE students logistic managers-by $3,14 \%$;

3. groups of HSE lecturers - students in the Center of Professional Advancement - by 5,2\%;

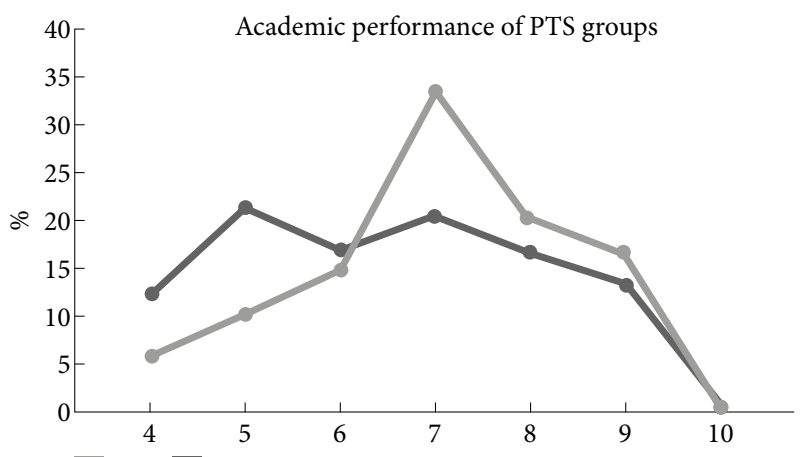

GL BC

Figure 10. The distribution of scores (from 4 to 10 points) in groups of students logistic managers using basic techniques (BC) and a technique using the graphic language (GL).

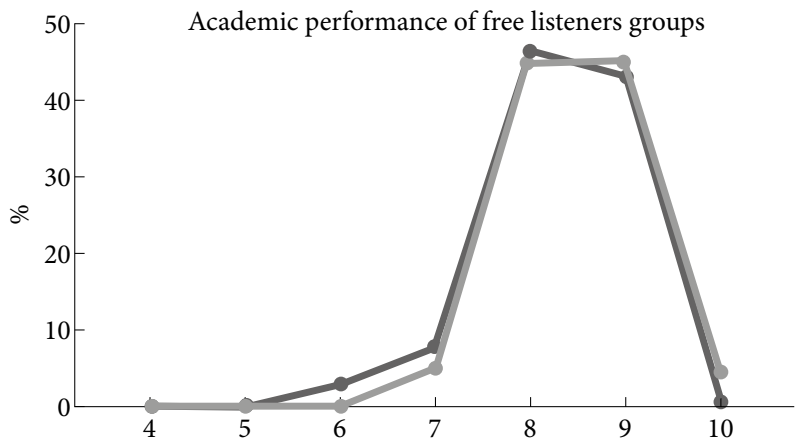

GL BC

Figure 12. Distribution of ratings (from 4 to 10 points) in groups of free listeners using basic methods (BC) and a technique using the graphic language (GL).

4. groups of free listeners (small groups) - by $0,89 \%$.

The results of the research show the effectiveness of the proposed methods of teaching and the relevance of the proposed new graphic language of English grammar.

\section{Conclusion}

Thus, we can say that such a system of visualization of rules in English grammar has several obvious advantages:

- the human brain memorizes the image much more readily and quickly than a sequence of statements that explain the meaning of the rules;

- the process of understanding is simplified, thanks to a schematic representation;

- memorizing speeds up; 
Table 3

Integrated assessment of quality indicators improvement $Q$ for different types of audiences

\begin{tabular}{lcccc}
\hline & I type of students & II type of students & III type of students & IV type of students \\
\cline { 2 - 5 } & $\begin{array}{c}\text { Students managers } \\
2014-2015\end{array}$ & $\begin{array}{c}\text { Students logistic } \\
\text { managers } \\
2014-2015\end{array}$ & $\begin{array}{c}\text { lecturers - students } \\
\text { in the Center } \\
\text { of Professional } \\
\text { Advancement 2014-2015 }\end{array}$ & $\begin{array}{c}\text { Free listeners } \\
2014-2015\end{array}$ \\
\hline $\mathrm{Q}$ & $2,88 \%$ & $3,14 \%$ & $5,20 \%$ & $0,89 \%$ \\
\hline $\mathrm{BP}$ & $53,33 \%$ & $58,10 \%$ & $51,02 \%$ & $96,43 \%$ \\
\hline $\mathrm{GL}$ & $64,84 \%$ & $70,64 \%$ & $71,70 \%$ & $100 \%$ \\
\hline
\end{tabular}

- the time spent on mastering grammar material reduces in general;

- motivation increases;

- it becomes possible to quickly and efficiently learn the greater volume of grammar.

It should be noted that the synthesis of new thought patterns in the grammar is a sign of intellectual information technologies.

The method of studying English grammar has been designed using information technology. The time formation visualization of English has been developed and systematized and is presented in a tabular form. The theoretical foundations of English grammar rules visualization using time-sequential scales for conversion in the sentences (in case of sequence of tenses) are presented.

The developed method of studying the English grammar for students was tested in a group of the Intermediate level. It showed high efficiency of storing large amounts of information.

System of graphic algorithms can be used as:

- teaching aids for English classes;

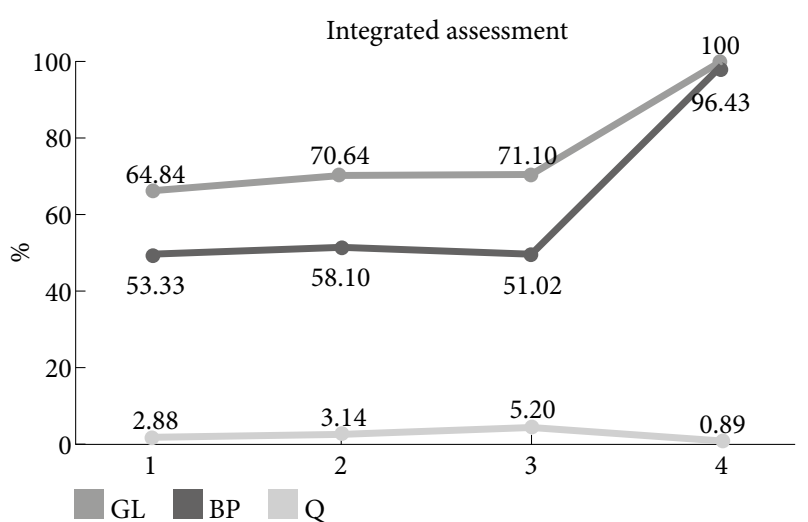

Figure 13. Integrated assessment of improvement of quality indicators $Q$ in teaching English with the introduction of a new technique that uses the proposed graphic language for different types of audiences.
- an intermediate form for the transition to a very compact binary formalization for automated computer translation.

Based on the developed theory, the algorithms, formalized in the functional sequence are worked out. They are essentially logical records of algorithms for automated translation, synthesis and editing of English texts.

The technique with the introduction of a graphical language of English grammar learning was tested at the National Research University Higher School of Economics in 4 types of groups of students, on the samples of 302 and 310 students in 2013-2015. The technique showed its high efficiency in all types of groups, as evidenced by the results of monitoring.

\section{References}

Bershadskaya, T. S. (1984). Kurs teorii muzyiki [The course of music theory]. Leningrad, USSR: Muzyika.

Bress, T. (2013). Effective LabVIEW programming. New York, NY: NTS Press.

Brokgauz, F. A., \& Efron, I. A. (1890-1907). Entsiklopedicheskiy slovar [Thesaurus]. Retrieved from: http://www.infoliolib.info/sprav/brokgaus/

Capel, A., \& Sharp, W. (2012). Objective proficiency. Cambridge, UK: Cambridge University Press.

Cotton, D., Falvey, D., \& Kent, S. (2010). Language leader: Student's book. Harlow, UK: Pearson.

Darnell, K. (1996). Visual simulation with student VisSim. Boston, MA: PWS Pub. Co.

Dubinets, E. A. (1999). Znaki zvukov. O sovremennoy muzyikalnoy notatsii [Signs of sounds. Modern musical notation]. Kiev, Ukraine: Gamaun.

Dyakonov, I. M. (1990). Shumerskiy yazyik. Lingvisticheskiy entsiklopedicheskiy slovar [Sumerian language. Linguistic thesaurus]. Moscow, USSR: Sovetskaya entsiklopediya.

Fraser, N. (2012). Graphical languages. Retrieved from https://neil.fraser.name/news/2012/01/24/https:// 
neil.fraser.name/news/2012/01/24/

Hastings, B., Umninska, M., \& Chandler, D. (2010). Longman exam activator. Harlow, UK: Pearson.

Istoriya pisma: Evolyutsiya pismennosti ot drevnego Egipta do nashih dney [Writing history: Encyclopedia of writing from ancient Egypt to the present day]. (2002). Moscow, Russia: Eksmo.

Johnston, W. M., Hanna, J. R. P., \& Millar, R. J. (2004). Advances in dataflow programming languages (PDF). ACM Computing Surveys (CSUR), 36(1), 1-34.

Kay, S., \& Jones, V. (2007). Inside out: Student's book. Oxford, UK: MacMillan.

Kerr, F., \& Jones, C. (2010). Straightforward: Student's book. Oxford, UK: MacMillan.

Kondrashevskiy, A. F. (1998). Posobie po ieroglifike (pril. $k$ uchebniku «Prakticheskiy kurs kitayskogo yazyika») [Workbook on hieroglyphics, application to the textbook "Practical course of Chinese language"] Moscow, Russia: Muravey.

Kozlova, L. A., \& Trubochkina, N. K. (2014). Optimal graphic language of the English grammar. In Innovative information technologies. Part 1: Innovative information technologies in education (pp. 223-232). Moscow, Russia: HSE.

Kozlova, L. A., \& Trubochkina, N. K. (2014). Informacionnye tehnologii v anglijskoj lingvistike Vizualizaciâ pravil grammatiki [Information technology in English - Imaging of grammar rules] Informacionnye Tehnologii, 215(7), 42-49.

Murphy, R. (2010). English grammar in use. Cambridge, UK: Cambridge University Press.

Parr, E. (2007). Programmiruemyie kontrolleryi: Rukovodstvo dlya inzhenera [Programming controllers: Guidance for an engineer]. Moscow, Russia: BINOM. Laboratoriya znaniy.
Petrov, I. V. (2004). Programmiruemyie kontrolleryi. Standartnyie yazyiki $i$ priemyi prikladnogo proektirovaniya [Programming controllers. Standard languages and techniques of applied design]. Moscow, Russia: SOLON-Press.

Petrovskiy, N. S. (1958). Egipetskiy yazyik. Vvedenie $v$ ieroglifiku, leksiku $i$ ocherk grammatiki sredneegipetskogo yazyika [Egyptian language. Introduction to hieroglyphics, vocabulary and essay on mid-Egyptian language]. Leningrad, USSR: LGU.

Project, L. (2012). Super scratch programming adventure! Learn to program. San Francisco, CA: No Starch Press.

Swan, M. (2009). Practical English usage. Oxford, UK: Oxford University Press.

Talah, V. N., \& Kuprienko, S. A. (2013). Amerika pervonachalnaya. Istochniki po istorii mayya, naua (astekov) $i$ inkov [Original America. Sources on the history of the Maya, Aztecs and Incas]. Kiev, Ukraine: Vidavets KuprIEnko S.A.

Thompson, A. J., \& Martinet, A. V. (2010). A practical English grammar. Oxford, UK: Oxford University Press.

Yule, G. (2012). Oxford practice grammar. Oxford, UK: Oxford University Press.

Velikaya, E. V. (2014). How to make teaching and assessment in ESP more efficient: Suggestions from university experience. Professional and Academic English, 44, 25-30.

Volkova, I. A., \& Rudenko, T. V. (1999). Formalnye grammatiki ijasyki [Formal grammar and languages]. Moscow, Russia: Moscow State University.

Zenkin, A. A. (1991). Kognitivnaya kompyuternaya grafika [Cognitive computer graphics]. Moscow, USSR: Nauka. 